Noman 2016, 34(2), 59-66

Revista de Psicologia, Ciències de l'Educació i de l'Esport

ISSN: 1138-3194

Copyright (c) 2016

www.revistaaloma.net

\title{
Video Gaming and Gender Dysphoria: Some Case Study Evidence
}

\author{
Mark D. Griffiths ${ }^{1}$, Jon Arcelus ${ }^{2,3}$ and Walter Pierre Bouman ${ }^{2}$ \\ ${ }^{1}$ Nottingham Trent University \\ ${ }^{2}$ Nottingham National Centre for Gender Dysphoria, Nottingham (United Kingdom) \\ ${ }^{3}$ Division of Psychiatry and Applied Psychology, Faculty of Medicine \& Health Sciences, \\ University of Nottingham (United Kingdom)
}

Received: 19-04-2016

Accepted: 02-06-2016

\section{Video Gaming and Gender Dysphoria: Some Case Study Evidence}

\begin{abstract}
Summary. Video gaming has become an established area of psychological research over the last two decades. Over the past few years there has been increasing research into online gender swapping, showing that for many groups or individuals it can have positive psychological benefits (e.g., as a way to explore gender roles and boundaries in a safe environment). To date, no research has ever examined online gender swapping among individuals with gender dysphoria - people with acknowledged gender-identity issues. Using four case studies, this exploratory study examined the role of gaming in the life of individuals seeking treatment for gender dysphoria. The main objectives were to use exemplar case studies to highlight that gaming - in some circumstances - appears to be a functional way of dealing with gender identity issues, and that gender swapping in gaming may help such individuals to come to terms with their gender dysphoria. Recommendations for further research are suggested along with the limitations of the data collected.
\end{abstract}

Key words: video gaming; Online gaming; Online videogames; Gender dysphoria; Transsexualism; Case series

\section{Jocs de vídeo i disfòria de gènere: Alguns estudis de casos}

Resum. Durant les últimes dues dècades, els videojocs han anat ocupant un camp establert de la investigació psicològica. En els últims anys hi ha hagut un augment de la investigació sobre el canvi de gènere online, mostrant que per a molts grups o individus això pot tenir beneficis psicològics (per exemple, com una manera d'explorar les funcions i els límits de gènere en un entorn segur). Fins a la data, cap investigació ha examinat el canvi de gènere online en els individus amb disforia de gènere - persones amb problemes d'identitat de gènere. Utilitzant quatre estudis de cas, aquest estudi exploratori va examinar el paper del joc en la vida dels individus que busquen tractament per disforia de gènere. Els objectius principals eren d'usar estudis de casos exemplar per mostrar que jugar jocs online pot ser - en algunes circumstàncies - una manera funcional de tractar amb problemes d'identitat de gènere, $i$ que el canvi de gènere en els jocs poden ajudar aquests individus a millorar la disforia de gènere. Es discuteixen les limitacions de les dades recollides i es suggereixen recomanacions per a futures investigacions.

Paraules clau: jocs de vídeo; jocs en línia; videojocs en línia; disfòria de gènere; transsexualitat; sèries de casos

Correspondence:

Prof. Dr. Mark Griffiths

International Gaming Research Unit, Psychology Department, Nottingham Trent University, Burton Street, Nottingham, NG1 4BU

mark.griffiths@ntu.ac.uk 


\section{Introduction}

Video gaming has attracted increasing research interest over the last two decades (Griffiths, Kiraly, Pontes \& Demetrovics, 2015). This has included much research into both the positives and negatives of gaming and into various topics such as gaming motivation (e.g., Kahn et al. 2015; Yee, 2006), the psychosocial consequences of gaming (Kowert et al., 2015), female gaming and gender differences in gaming (e.g., Lewis \& Griffiths, 2011; McLean \& Griffiths, 2013; Todd, 2012), the personality characteristics of gamers (e.g., Spekman et al., 2013), and game transfer phenomena (Ortiz de Gortari \& Griffiths, 2015). One area that has received relatively little research attention is online gender swapping during gaming. This area is briefly reviewed in the next section.

\section{Gender swapping in online gaming}

Huh and Williams have defined in-game gender swapping as «a difference between the gender reported by the player in the survey from the gender of the player's main character in the game» (p.161). To date, very few studies have examined gender swapping in online gaming. Using secondary polling data from online gaming forums, Griffiths, Davies and Chappell (2003) reported that of 10,350 players at the Everlore fan site, $15 \%$ had engaged in gender swapping with their main in-game character. They also reported a similar finding among 8,694 players at the Allakhazam fan site, with $15.5 \%$ reporting that they had gender swapped their main in-game character (and more specifically, 14.5\% males and $1 \%$ were females who had changed gender of their lead character (prior to playing the game). In a survey study on 540 Everquest gamers, Griffiths, Davies and Chappell (2004) reported that 60\% had gender swapped their online in-game characters. The apparent prevalence of gender swapping was probably much higher in this study because the question related to the gender swapping of any online game character rather than just each player's main character. In a small exploratory survey, Hussain and Griffiths (2008) examined why people engage in gender swapping in a self-selecting sample of 119 online gamers (mean age of 28.5 years). They reported that $57 \%$ of gamers had engaged in gender swapping (any character, not just their main character), and that males adopting an online female persona believed a number of positive social implications could result from becoming female characters in male-oriented gaming environments. The study also reported that significantly more females than males had gender swapped their character - mainly to avoid unsolicited male attention to their female characters. Some females appeared to gender swap purely out of interest to see what would happen in the game (as a personal experiment), while others claimed that they were treated more favourably by male gamers when they played as male characters. Others reported that gender swapping enabled them to play with aspects of their identities that would not be possible to explore in real life. Other reasons for gender swapping were that (i) female characters had better in-game statistics, (ii) some specific tools were only available to female characters, (iii) the class of character was sometimes only available in one gender, (iv) they played for fun, and/or (v) they wanted a departure from what they would normally do in the game (i.e., they did it for a change in their usual playing behaviour).

In an ethnographic study of female EverQuest players, Taylor (2003) also reported that some players engaged in gender swapping (although did not report how common it was). However, she noted:

"One of the more interesting aspects to consider is the way the game may allow access to gender identities that are often socially prohibited or delegitimised offline simultaneously sexy and powerful or masculine and beautiful identities. Women in EverQuest are constantly playing with traditional notions of femininity and [they] reformulate gender identities through aspects of the space that are directly tied to its nature as a game» (p.27).

Using survey data, Huh and Williams (2010) examined gender swapping in EverQuest II. Unlike in the few previous studies, they reported that gender swapping was less common among female players and that the phenomenon overall was rare. They also reported that homosexual players were more likely than heterosexual players to gender swap while gaming online. Males who played as female characters were no more likely to engage in stereotypically female acts than males that played as male characters. However, they did note that females who played male characters displayed a degree of hyper-masculine behaviour. The authors concluded that there may be less gender identity exploration or challenging of gender norms than had been reported in previous literature.

In a small qualitative study, Todd (2012) examined the relationship between gender and gaming among eight mature New Zealand female gamers (all 30 years of age or older) and how they negotiated their 'real-life' identities with their 'virtual' gaming identities. Based on the experiences of the women interviewed, Todd concluded that although within gaming spaces gender swapping is a normative practice, these acts of 'genderbending' do little to challenge notions of gender.

Beyond online gaming, Hegland and Nelson (2002) noted that the Internet more generally can be used as a tool for expressing gender identity because it allows identities to cross cultural boundaries instantly and without regard for real physical space. They examined 30 cross-dressing websites and argued that for most cross-dressers who visited the websites found their primary medium of expression in these online fora. The websites guided users and nurtured their ability to create a feminine identity, and helped them to pass as women in the offline public world. More generally, cross-dressers used the Internet to participate in the larger cultural dialogue on gender. 
Osborne (2012) has noted that online role-playing games (MMORPGs) provide a structure within which gamers enact the gender and sexuality of their avatars. She conducted a survey to study how role-playing gamers perceived and performed their avatars' genders and sexualities in online games. A qualitative analysis of the data suggested that those gamers who displayed empathy with and examination of their avatars' genders and sexualities, and who experienced a sense of belonging within the game structure, were able to form positive interpersonal relationships that allowed them to accept others' expressed identities.

There have been studies of how gamers and fans play with sexuality, gender, and the video game Minecraft on YouTube (Potts, 2015), as well as papers discussing whether the gaming industry should cater to marginalized groups and develop games for groups for whom there is little representation within games (e.g., gay and transgendered characters) (Shaw, 2012). For instance, there is now a short autobiographical game (http://www. newgrounds.com/portal/view/591565) by Auntie Pixellante called Dys4ia. This is a WarioWare-style game, played only with the arrow keys, chronicling the experiences of a trans woman as she addresses her own gender dysphoria. Such videogames raise interesting questions about how those individuals with gender dysphoria utilize gaming as part of their identities. The next section establishes a framework for the description of this study with a discussion of the condition of gender dysphoria and how it has been defined and conceptualised.

\section{Gender Dysphoria}

For an adult to meet the current criteria for a diagnosis of transsexualism, the International Classification of Diseases version 10 (ICD-10) says that the individual must express the desire to live and be accepted as a member of the opposite sex, usually accompanied by the wish to make his or her body as congruent as possible with the desired sex through surgery and cross-sex hormones. This transsexual identity must have been present persistently for a minimum of two years and not be a symptom of another mental disorder or a chromosomal abnormality (World Health Organisation, 1992).

The latest (fifth) edition of Diagnostic and Statistical Manual of Mental Disorders (DSM-5) of the American Psychiatric Association (APA; 2013) uses the term gender dysphoria to describe people who are uncomfortable and/or distressed regarding their assigned gender, their physical sex characteristics and/or their associated social roles. Depending upon the intensity of this distress, some individuals may wish to transition from one point on a notional gender scale to another. The most common direction is from a man to a woman (individuals known as trans women), or from a woman to a man (individuals known as trans men) (Ahmad et al., 2013; Coleman et al., 2012; Wylie et al., 2014). The distress intrinsic to gender dysphoria may be focused around anatomy, physiology, and/or being perceived and treated as someone of a gender with which the person does not identify (Bouman et al., 2010). However, for a multitude of reasons, these diagnostic labels do not apply to all trans individuals, because some people do not identify themselves either as men or women (Ahmad et al., 2013; Bouman \& Richards, 2013; Davies et al., 2013; Richards et al., 2016; Wylie et al., 2014).

Similar to the DSM-5 (APA, 2013), it is expected that the forthcoming edition of the ICD (ICD-11), due to be released in 2017, will present a new diagnostic term to include those who fall outside of the traditional gender binary (Drescher, Cohen-Kettenis, \& Winter, 2012). The World Health Organisation working group has recommended that the ICD-11 replace the term Transsexualism with Gender Incongruence (Drescher et al., 2012) and remove it from the mental and behavioural disorders chapter. Gender incongruence denotes the incongruence between a person's gender identity and their assigned sex and/or congenital primary and secondary sex characteristics (Beek, Cohen-Kettenis, \& Kreukels, 2016).

The terminology in this field has changed over the years and the terms 'transgender' and 'trans' have been used in the literature as umbrella terms to cover a wide variety of atypical gender experiences and expressions which may lead to permanent change of social gender role but do not necessarily involve treatment with cross-sex hormones or surgical intervention. A recent study reported an overall meta-analytical prevalence of transsexualism of 4.6 out of 100,000 individuals; 6.8 for trans women and 2.6 for trans men, figures which are primarily based on studies looking at individuals who seek clinical services (Arcelus et al., 2015).

However, recent population studies have reported a significantly higher prevalence rate of atypical gender experiences and expressions. Kuyper and Wijsen (2014) examined self-reported gender identity and dysphoria in a large Dutch population sample $(\mathrm{N}=8,064$, aged 1570 years old), and found that $4.6 \%$ of people assigned male at birth and $3.2 \%$ of people assigned female at birth reported an 'ambivalent gender identity' (defined as an equal identification with another sex and with the sex assigned at birth). Furthermore, $1.1 \%$ of people assigned male at birth and $0.8 \%$ of people assigned female at birth reported an 'incongruent gender identity' (defined as stronger identification with another sex than with the sex assigned at birth). More recently, Van Caenegem et al. (2015) reported similar results based on two population-based surveys in Flanders (Belgium) examining the prevalence of 'gender incongruence' (defined as identifying more strongly with the other sex than with the sex assigned at birth) and 'gender ambivalence' (defined as identifying equally with the other sex as with the sex assigned at birth). Their findings showed gender ambivalence was present in $2.2 \%$ of male and $1.9 \%$ of female participants, whereas gender incongruence was found in $0.7 \%$ of men and $0.6 \%$ of women.

\section{Background and objectives to the present study}

The present study has its origins in initial observations made by the second and third authors that a number of 
gender dysphoric clients presenting at their clinic reported that they gender-swapped while playing online games. After meeting with the first author, who has been conducting research in the gaming studies field for three decades, the first author suggested that the second and third authors revisit their case files and re-evaluate the extent to which gender swapping within online gaming had become a strategy in helping to deal with their offline gender identity, and to write them up as case studies (as no study in the gaming field has ever examined online gaming among those with gender dysphoria). As this is an exploratory study, there were no hypotheses, and since the case records were re-evaluated retrospectively, the authors could only report information that was in the case files (information that was gathered prior to undertaking a study focussed on gaming and gender dysphoria). The main objectives were to use exemplar case studies to highlight that gaming - in some circumstances - appears to be a functional way of dealing with gender identity issues and that gender swapping may help individuals to come to terms with the fact that they feel they were biologically born a different gender from that which they hope to become.

\section{Method}

The following case studies relate to four people who attended an assessment at the National Centre for Gender Dysphoria in Nottingham. The Centre, which is part of the UK National Health Service (NHS) offers assessment and treatment to individuals with gender dysphoria free at the point of access. Patients are usually referred by their general practitioner. The assessment involves information gathering by two independent gender specialists in two separate and independent assessment meetings. In order for a person to be accepted into the treatment program, following their assessment, they have to: (i) fulfil the diagnostic criteria for Transsexualism in the ICD-10 (World Health Organization, 1992), (ii) undertake social role transition including name change and the provision of additional documentary evidence to support social gender role transition, and (iii) be absent of any major comorbid mental health problems, which will make transitioning towards their experienced gender difficult. The treatment program consists of cross-sex hormone prescription and monitoring, psychological support as required, voice coaching, and facial hair removal referral for trans women. Following a successful period within the treatment program (usually between 1 and 2 years) people may be referred for sex re-assignment surgery if they so wish.

The data presented below are in the form of four brief case study reports, as examples of the increasing number of patients describing online video gaming behaviour, using material relating to the issue of gaming excess, addiction, and the context in which the gaming occurred in people referred to the Centre. All of the individuals described are given pseudonyms and the contents of their histories are anonymised.

\section{Results}

Case study 1: Mary

Mary is a 26-year old natal male who fully transitioned to the female social role six months prior to the present study. Consequently, the feminine pronoun will be used in this case study to refer to her. She described an early history of being isolated as a child and not having very many friends in primary and secondary school. As a young person she was not interested in sports, but preferred reading, particularly fantasy and science-fiction genre books. From a very early age, she hated wearing jeans and other male clothing and fantasised about wearing skirts and girls' clothes. From the age of 14 years she spent up to 5 hours a day in an online gaming forum. There, she always took on a female persona with a female name, and she had people refer to her with female pronouns and would play online games with female avatars. At first, she said she was not sure why she did this but that she always enjoyed the female characters more than the male characters, and she enjoyed being treated as a female. She very much enjoyed dressing her avatars in their female outfits. She explained that this behaviour felt right to her. In her real life (and prior to puberty), she remembers being teased for looking like a girl, and people used to ask her if she was a boy or a girl. She said that people would tease her as she enjoyed «more girly things», like playing with dolls.

She gradually retreated more and more to the online gaming world to the point where one of her online friends became concerned that she was becoming «obsessed» and losing touch with "real life». At this point Mary was using two personae online, one male and one female, although she consistently used the female persona more frequently than the male one. Mary's friends told her that she needed to stop playing online games. She became upset about this and decided to drop the male persona while making the female persona more ambiguous and androgynous. However, she experienced an overarching feeling when she was 16 years old that she just wanted to tell everybody that she felt she was a girl. Up until that point, she had only explored this side of her persona online, as she did not feel it was possible in the real world. She explained that she started feeling happier in the online world than in her real world, as she could be herself. This developed into spending more time in online gaming and isolating herself further socially. She lost most of her friends, her grades dropped and she only communicated with her one online girlfriend. She ended up struggling with her A-level results during this period.

After not doing very well in her A-levels (i.e., advanced educational qualifications in the UK), Mary trained as a mechanic (almost totally a male occupation in the UK) because she still lived full-time as a male. She tried to make more friends and started going to Warhammer meetings, but even then there was still very limited interaction with other people. Then, Mary met a trans woman online and she started to explore her trans feelings. Following conversations with her 
trans friend, she decided that she wanted to explore her female side, and she started to cross-dress at home. She said that it felt right and explained that this was a feeling that she had not experienced before. From that point onward, Mary decided to come out to her parents as a trans woman. She was surprised to find out that they were very supportive. Mary was then assessed at the Centre, and was started on cross-sex hormones. She is now doing much better socially and has started a college 'access to higher education' course. Looking back, Mary said that it was thanks to the online game that she did not become depressed. She explained: «I was able to be myself in the online world and by doing so I found out who I really was».

\section{Case study 2: 'Mark'}

Mark is a 20-year old natal female who first attended for an assessment in the female role. However, he would like to be known as male and with the name of Mark. He has a background of autistic spectrum disorder, has suffered from depression, and has a long history of deliberate self-harm. When he was young, he played with stereotypically female toys that his parents gave him such as My Little Pony. He described himself as a loner with no friends. As he got older, he became more and more interested in videogames. When he was around seven years old, he said he really enjoyed playing on both the Dreamcast and PlayStation videogame consoles, enjoying adventure games and playing videogames as a male character. He said that playing as a male character "felt right» and that playing as a female character made little sense to him. He said that during this period, his parents would dress him in typical female clothing, which he hated. At secondary school, Mark preferred to wear jeans and more stereotypical male clothing. He disliked wearing skirts and refused to wear them as part of his school uniform.

While he was at secondary school, his gaming habit further developed and he increasingly began to play adventure role-playing games, particularly World of Warcraft, in which his identity would always be male. He liked to imagine that other people would think of him as male in the game. His gaming handle (i.e., his name) became 'Mark', and he now considers this as his male name (both online and offline). He very much preferred questing as a male character in the online games he played. Mark remembered that when he was 14 years old he would look at his body and feel that it - and in particular his genitals - were not right. Consequently, he would engage in deliberate self-harm to punish himself for looking and feeling so ugly. About a year prior to the present study, Mark started to ask people - including his parents in the real world - to call him Mark, and to use the male pronoun. Mark binds his breasts and has done so for the last 4 years. He attended the Centre for assessment for his gender dysphoria. He explained that he wanted to be male and therefore wanted to take cross-sex hormones, such as testosterone. Ultimately, it was his online gaming experiences that led him to feel comfortable as a male.
Case study 3: 'Paul'

Paul is a 31-year old natal male who would like to be female, but he is still living full-time as a male. He is married and has two children. Paul started crossdressing (using his sister's clothes) at the age of 12. In the beginning, there was a sexual component to his cross-dressing activity. Gradually he started presenting more and more in a female role, but at the time he did not have any understanding as to why he did so. He felt confused and different to his friends. He described himself as shy and quiet, and he had few friends of either gender. He loved playing videogames, particularly Super Mario Kart and Zelda. He also played football with friends. Paul trained as a personal trainer and at this point he started drinking alcohol excessively as a way of "fitting in" and "and being [accepted by] lads». He explained that during this «very confusing» period for him, he developed a sense of escapism when he played Oblivion and other similar online role-playing games, mostly in the third-person. When he started playing as a female, he felt right and that it was natural. He liked the fact that other online gamers thought he was a woman, and he would always play as a female character and in a female role. He liked interacting online with people and he said that the gaming made him feel good about himself.

This was virtually the only expression of Paul's imagined gender at this point. He did not have the confidence to even extend his gender swapping to multi-playing. He got married in his early twenties and when living with his wife he continued to cross-dress in secret at home and wear female underwear. At this point he liked the way it felt and looked, but he got no sexual gratification from cross-dressing. He would very occasionally go out in full female role and he described this as feeling good, but a bit scary. He attended the Centre asking for help in coming out and in reaching a better understanding of his gender identity. He continues to play video games as a female character as a way of expressing his experienced gender in a safe environment. However, he is still uncertain about fully transitioning to being female.

\section{Case study 4: 'Harry'}

Harry is a 23-year old natal male who presented for an assessment as a male. He sees himself as female but has not yet transitioned. From about the age of 6 , he would play with his older brothers and always adopted a female role in the imaginary games they played. At that early age, he had already informed his brothers that he was «a girl», and he had very few friends. On his birthdays, he would always wish to wake up one day and be a girl, but it never came true. Puberty came as a shock to him, and it was at this stage of his life that he described strong dysphoric feelings towards his body that he tried to "blank out» and suppress. He became depressed and starting self-harming as a way of coping with his negative feelings about himself. He isolated himself from other people and developed social anxiety. At this point, he retreated into role-playing games 
such as Final Fantasy and Dragon Age, but he avoided online role-playing games because he felt they would be too scary. There were strong themes of escapism in his gaming. When he had a choice he would always play female characters as he said that this felt better and more comfortable for him than reality. He said he was able to escape even more into the video game if he was playing a female character.

As a result of playing video games continuously up to 12 hours a day as a way to cope with his feelings, his education suffered badly. However, he explained that the excessive gaming enabled him to stop self-harming. He hardly left his house due to his social anxiety and depression, and his GP subsequently referred him to a therapist. It was then that Harry disclosed his trans feelings. Harry ended up telling his parents about his gender dysphoria six months prior to the present study. They were shocked, but his mother has been supportive. However, his father remains bewildered and finds. Harry's desire to be female difficult to accept. Harry would like to transition, but his social anxiety does not allow him to. He still plays video games obsessively and is housebound. He is unsure what the future will bring. As far as social gender role expression is concerned, Harry only ever engaged in wearing female clothing when he was a young boy, whilst playing imaginary role-playing games with his brothers. There is an overall sense that he is stuck in his life and that playing video games excessively is his only way of coping with the distressing thoughts he has.

\section{Discussion}

The four case studies outlined in the present paper are only a selected sample of the number of cases attending a national clinic for people with gender dysphoria. They are in no way atypical of the clients that have sought help at the Centre. However, these individual accounts were specifically selected to demonstrate the different ways that video gaming may help people with gender dysphoria come to terms with their gender identity. For example, gaming can be used among trans people as a psychological tool to increase one's awareness of gender identity and/or as part of the self. Gaming may therefore be a useful way to express one's experienced gender identity in a safe, non-threatening, non-alienating, nonstigmatizing, and non-critical environment. This appears to mirror the findings of other studies outside of the online gaming environment. For instance, using virtual ethnography and discourse analysis within two online Israeli arenas (a newsgroup and an online forum), Marciano (2014) examined the ways that trans individuals manoeuvre between their online and offline worlds as a way of negotiating their gender identity and to overcome offline impediments. The results suggested that trans individuals used the online world as either a preliminary, complementary, and/or alternative medium which gave them more space to negotiate their gendered status - a pattern that was also found among the case studies in the present study.
Articles published in the mass media have reported that online games such as World of Warcraft provide a creative space that allows gamers that might be questioning aspects of their identity to explore their lives as different individuals. Some have even gone as far as to argue that this could help gamers transform their 'offline' identity, as is the case with some trans gamers (Dale, 2014). This was also demonstrated in the case studies described in the present study. Other authors (e.g., Zoonen, 2002; Fahs \& Gohr, 2012) assert that the online medium offers an infinite space for development and resistance to traditional gender roles, and that online interaction enables a transgression of the dichotomous categories of male and female, constructing non-binary (or even genderless) social identities and relationships. However, although such anonymous online communities may provide trans individuals with the power to subvert their physical sex (Laukkanen 2007), such categorisation brings with it often «harsh, hegemonic performance expectations and pressures» (Fahs \& Gohr, 2012; p.27).

The case studies presented here also demonstrated the different functions gaming has for trans people (e.g., the function of «testing out» their gender feelings). For instance, some can use gaming to 'come out' to other people, by initially coming out in the online community, which is perceived as a safe environment, and then gradually coming out in real life. As it does for many cisgendered individuals gaming can provide trans people with psychological benefits and a sense of escapism. This is even more relevant among trans people, as it may be the only time that they feel they can be themselves, allowing them to feel happy and relaxed and to achieve a sense of completeness. This could develop into a powerful coping skill that might keep these individuals from resorting to unhealthy behaviours such as self-harming. This is particularly important in this population, as research shows a strong association between being trans and mental health problems, particularly depression and self-harm as a way to manage one's trans feelings (Claes et al., 2015; Davey et al., 2015; Hepp, Kraemer, Schnyder, Miller, \& Delsignore, 2005; Marshall et al., 2016; Nuttbrock et al., 2010; Operario \& Nemoto, 2005). This is not surprising, as the discomfort and distress about assigned gender and body dissatisfaction (Witcomb et al., 2015; Jones et al., 2016) may lead to a sense of hopelessness, which can bring with it low mood, selfinjury and even suicide (Dhejne et al., 2011).

Although gaming appears (at least initially) to be a positive and beneficial activity for many trans people, there is also the risk that staying within the world of the game becomes too much of a secure and safe environment. This can create a vicious circle where the trans person does not wish to move out of the secure online world and back into reality. Spending an increasing amount of time on online gaming carries the risk of developing a gaming dependence or addiction (Lopez-Fernandez et al., 2014; Pontes \& Griffiths, 2015). This may not only affect one's personal relationships, 
work and/or study, but may also impair real life social gender role transition, as in many cases the individual is expected to socially transition before they can be considered for treatment.

The present study is not without its limitations. The number of participants $(n=4)$ was small, and although the cases studied were typical of those with gender dysphoria attending the clinic, they are unlikely to be representative of those with gender dysphoria more generally. The case studies reviewed may be perceived by some researchers as 'anecdotal' because the data were not collected for this specific study but were retrospectively collated. The insights concerning both positive and negative aspects of gaming by those with gender dysphoria would need to be confirmed using larger and more representative samples. For a trans individual, the online gaming environment is perceived as «safe», but further research is needed to establish what distinctive elements of online gaming help to raise gender awareness (or not, as the case may be). The present study cannot answer such questions as none of the individuals in the present study was specifically asked about their gaming experiences (because the original case notes taken by the therapists were not specifically concerned with gaming but were a general case assessment). Consequently, only one of the individuals specifically described their motives and relationship with online gaming and/or their avatars. It could be that some individuals with gender dysphoria suffer negative experiences of gaming in the long run because the individual may simply not be able adopt such a role in real life.

With the rates of gender dysphoria attending clinical services increasing significantly (de Vries et al., 2015), future research should investigate (i) the rates of gaming addiction among this population as well as its function, and (ii) the rates of gender dysphoria among game addicts as coming out may help their addiction. The game industry may want to consider how they can use games as a way of helping trans people being more accepted within society by developing game industry may want to observe how their games can prepare and assist individuals to transition socially. Online games also provide a safe environment that gives people access to a platform where they can discuss and experiment with gender identity.

\section{References}

Ahmad, S., Barrett, J, Beaini, A., Bouman, W.P., Davies, A., avStradins L (2013). Gender dysphoria services: A guide for general practitioners and other healthcare staff. Sexual and Relationship Therapy, 28, 173-186.

American Psychiatric Association (2013). Diagnostic and Statistical Manual of Mental Disorders-5 ( $5^{\text {th }} \mathrm{ed}$.). Washington, DC: American Psychiatric Association.

Arcelus, J., Bouman, W. P., Witcomb, G. L., Van den Noortgate, W., Claes, L., \& Fernandez-Aranda, F. (2015). Systematic review and meta-analysis of prevalence studies in transsexualism. European Psychiatry, 30, 807-815.
Beek, T., Cohen-Kettenis, P. T., Kreukels, B. P. C. (2016). Gender incongruence/gender dysphoria and its classification history. International Review of Psychiatry, $8(1), 5-12$.

Bouman, W. P., Bauer, G. R., Richards, C., \& Coleman, E. (2010) WPATH consensus statement on considerations on the role of distress (Criterion D) in the DSM diagnosis of gender identity disorder. International Journal of Transgenderism, 12(2), 100-106.

Bouman, W. P. \& Richards, C. (2013). Diagnostic and treatment issues for people with gender dysphoria in the United Kingdom. Sexual and Relationship Therapy, 28(3), 165-171.

Claes L, Bouman WP, Witcomb GL, Thurston M, Fernandez-Aranda F, \& Arcelus J (2015). Non-suicidal self-injury in trans people: Associations with psychological symptoms, victimization, interpersonal functioning and perceived social support. Journal of Sexual Medicine, 12(1), 168-179.

Coleman, E., Bockting, W., Botzer, M., Cohen-Kettenis, P., De Cuypere, G., e,\& Zucker K. (2012). Standards of care for the health of transsexual, transgender, and gender-nonconforming people, version 7. International Journal of Transgenderism, 13, 165-232.

Dale, L. K. (2014, January 23). How World of Warcraft helped me come out as transgender. The Guardian. Retrieved from http://www.theguardian.com/technology/gamesblog/2014/jan/23/how-world-of-warcraft-game-helped-me-come-out-transgender

Davey, A., Arcelus, J., Meyer, C., \& Bouman, W. P. (2015). Self-injury among trans individuals in transition and matched controls: Prevalence and associated factors. Health \& Social Care in the Community. Epub ahead of print. doi: 10.1111/hsc.12239

Davies, A., Bouman, W. P., Richards, C., Barrett, J., Ahmad, A., hm\& Stradins L (2013). Patient satisfaction with gender identity clinic services in the United Kingdom. Sexual and Relationship Therapy, 28(4), 400-418.

de Vries, A. L. C., Kreukels, B. P. C., T’Sjoen, G., Algars, M,. \& Mattila, A. (2015). Increase of referrals to gender identity clinics: A European trend? In: Transgender Healthcare in Europe. Book of Abstracts (p.10). Ghent, Belgium: European Professional Association of Transgender Health.

Dhejne, C., Lichtenstein, P., Boman, M., Johansson A. L. V., Langstrom, N. \& Landen, M (2011). Long-term follow-up of transsexual persons undergoing sex reassignment surgery: Cohort study in Sweden. PLoS ONE, 6(2), e16885.

Griffiths, M. D., Davies, M.N.O. \& Chappell, D. (2003). Breaking the stereotype: The case of online gaming. CyberPsychology and Behavior, 6, 81-91.

Griffiths, M.D., Davies, M.N.O. \& Chappell, D. (2004). Demographic factors and playing variables in online computer gaming. CyberPsychology and Behavior, 7, 479-487.

Griffiths, M. D., Kiraly, O., M. Pontes, H. M. \& and Demetrovics, Z. (2015). An overview of problematic gaming. In Starcevic, V. \& Aboujaoude, E. (Eds.), 
Mental Health in the Digital Age: Grave Dangers, Great Promise (pp.27-55). Oxford: Oxford University Press. Fahs, B., \& Gohr, M. (2012). Superpatriarchy meets cyberfeminism: Facebook, online gaming, and the new social genocide. MP: An Online Feminist Journal, 3(6), 1-40.

Hegland, J. E., \& Nelson, N. J. (2002). Cross-dressers in cyber-space: Exploring the Internet as a tool for expressing gendered identity. International Journal of Sexuality and Gender Studies, 7(2-3), 139-161.

Hepp, U., Kraemer, B., Schnyder, U., Miller, N., \& Delsignore, A. (2005). Psychiatric comorbidity in gender identity disorder. Journal of Psychosomatic Research, 58, 259-261.

Huh, S., \& Williams, D. (2010). Dude looks like a lady: Gender swapping in an online game. In Online worlds: Convergence of the real and the virtual (pp. 161-174). London: Springer.

Hussain, Z., \& Griffiths, M. D. (2008). Gender swapping and socialising in cyberspace: An exploratory study. CyberPsychology and Behavior, 11, 47-53.

Jones, B.A., Haycraft, E., Murjan, S., \& Arcelus, J. (2016). Body dissatisfaction and disordered eating in trans people: A systematic review of the literature. International Review of Psychiatry, 28(1), 81-94.

Kahn, A. S., Shen, C., Lu, L., Ratan, R. A., Coary, S., Hou, J., ... \& Williams, D. (2015). The Trojan Player Typology: A cross-genre, cross-cultural, behaviorally validated scale of video game play motivations. Computers in Human Behavior, 49, 354-361.

Kowert, R., Vogelgesang, J., Festl, R., \& Quandt, T. (2015). Psychosocial causes and consequences of online video game play. Computers in Human Behavior, 45, 51-58.

Kuyper, L., \& Wijsen, C. (2014). Gender identities and gender dysphoria in the Netherlands. Archives of Sexual Behavior, 43(2), 377-385.

Lewis, A., \& Griffiths, M. D. (2011). Confronting gender representation: A qualitative study of the experiences and motivations of female casual-gamers. Aloma: Revista de Psicologia, Ciencies de l'Educacio i de l'Esport, 28, 245-272.

Lopez-Fernandez, O., Honrubia-Serrano, M. L., Baguley, T. \& Griffiths, M. D. (2014). Pathological video game playing in Spanish and British adolescents: Towards the Internet Gaming Disorder symptomatology. Computers in Human Behavior, 41, 304-312.

Marshall, E., Claes, L., Bouman, W. P., Witcomb, G.L. \& Arcelus, J. (2016). Non-suicidal self-injury and suicidality in trans people: A systematic review of the literature. International Review of Psychiatry, 28(1), 58-69.

Marciano, A. (2014). Living the VirtuReal: Negotiating transgender identity in cyberspace. Journal of Computer-Mediated Communication, 19(4), 824-838.

McLean, L., \& Griffiths, M. D. (2013). Female gamers: A thematic analysis of their gaming experience. International Journal of Games-Based Learning, 3(3), 54-71.
Nuttbrock, L., Hwahng, S., Bockting, W., Rosenblum, A., Mason, M., Macri, M., \& Becker, J. (2010). Psychiatric impact of gender-related abuse across the life course of male-to-female transgender persons. Journal of Sex Research, 47(1), 12-23.

Operario, D., \& Nemoto, T. (2005). Sexual risk behavior and substance use among a sample of Asian Pacific Islander transgendered women. AIDS Education and Prevention, 17, 430-443.

Ortiz de Gortari, A.B., \& Griffiths, M. D. (2015). Game Transfer Phenomena and its associated factors: An exploratory empirical online survey study. Computers in Human Behavior, 51, 195-202.

Osborne, H. (2012). Performing self, performing character: Exploring gender performativity in online role-playing games. Transformative Works and Cultures, 11. doi:10.3983/twc.2012.0411.

Pontes, H. \& Griffiths, M. D. (2015). Measuring DSM-5 Internet Gaming Disorder: Development and validation of a short psychometric scale. Computers in Human Behavior, 45, 137-143.

Potts, A. (2015). 'LOVE YOU GUYS (NO HOMO)' How gamers and fans play with sexuality, gender, and Minecraft on YouTube. Critical Discourse Studies, 12(2), 163-186.

Richards, C., Bouman, W. P., Seal, L., Barker, M.J., Nieder, T. O., \& T'Sjoen, G. (2016). Non-binary or genderqueer genders. International Review of Psychiatry, 28, 95-102.

Spekman, M. L. C., Konijn, E. A, Roelofsma, P. H. M. P. \& Griffiths, M. D. (2013). Gaming addiction, definition, and measurement: A large-scale empirical study, Computers in Human Behavior, 29, 2150-2155.

Shaw, A. (2012). Do you identify as a gamer? Gender, race, sexuality, and gamer identity. New Media and Society, 14(1), 28-44

Taylor, T. L. (2003). Multiple pleasures women and online gaming. Convergence: The International Journal of Research into New Media Technologies, 9(1), 21-46.

Todd, C. (2012). 'Troubling' gender in virtual gaming spaces. New Zealand Geographer, 68(2), 101-110.

Van Caenegem, E., Wierckx, K., Elaut, E., Buysse, A., Dewaele, A., e,\& T'Sjoen, G. (2015). Prevalence of gender nonconformity in Flanders, Belgium. Archives of Sexual Behavior. DOI 10.1007/s10508-014-0452-6

Witcomb, G. L., Bouman, W. P., Brewin, B., Richards, C., Fernandez-Aranda, F., \& Arcelus, J. (2015). Body image and eating disorders psychopathology in trans individuals: A matched control study. European Eating Disorders Review, 23, 287-293.

World Health Organisation (1992). International Classification of Diseases 10 (2nd ed.). Geneva: WHO.

Wylie, K.R., Barrett, J., Besser, M., Bouman, W. P., Bridgeman, M., ... \& Ward, D. (2014). Good practice guidelines for the assessment and treatment of adults with gender dysphoria. Sexual and Relationship Therapy, 29(2), 154-214.

Yee, N. (2006). Motivations for play in online games. CyberPsychology and Behavior, 9, 772-775. 